\title{
CONF-960421--23
}

\section{DEFINING THE POTENTIAL REPOSITORY SITING BLOCK YUCCA MOUNTAIN, NEVADA}

Robert W. Elayer

Morrison Knudsen Corporation

101 Convention Center Drive

Las Vegas, NV 89109

(702) 794-1960
Richard. M. Nolting III

Morrison Knudsen Corporation

101 Convention Center Drive

Las Vegas, NV 89109

(702) 794-1833

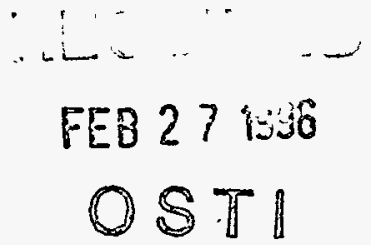

\section{BACKGROUND}

Siting activities for the potential high-level nuclear waste repository at Yucca Mountain focused on locating a suitable host geologic horizon above the water table. The Topopah Spring Tuff of the Paintbrush Group was identified as the most suitable geologic unit. Sandia National Laboratories (Sandia) identified six areas as potential repository sites ${ }^{t}$. Area 1 , known as the Primary Area, is the site of the present characterization and design activities ${ }^{2}$.

To support current repository Advanced Conceptual Design, a reevaluation of the Primary Area was conducted by the Yucca Mountain Project's Management and Operating Contractor (M\&O). The purpose of the study was to more precisely define the block volume that would be suitable for siting the repository ${ }^{3}$. The Lynx Geoscience Modeling software (Lynx) was selected to be used in this work because of its three-dimensional modeling and visualization capability for geology and underground excavation design. The Lynx model YMP.MO2 was developed in the study. The model includes surfaces that were constructed to represent each of the following limiting criteria: faults, overburden, repository host horizon, and groundwater. The resulting potential repository siting block is the useable volume within these limiting criteria.

\section{FAULTS}

The limits of the Primary Area generally coincide with the Solitario Canyon fault on the west, Drill Hole Wash fault on the north, western limit of the Imbricate fault system on the east, and Abandoned Wash fault on the south. Identified faults located within the Primary Area include the Ghost Dance fault and Sundance fault. For modeling, fault characteristics were taken from the Lynx

geology model YMP.R1.1, which was developed by the U.S. Geological Survey ${ }^{4}$. For design purposes, the repository standoff from Quaternary faults (active within last 2-million years) is assumed to be adequate by using 60 meters ${ }^{2}$. For current design, the Solitario Canyon fault, Drill Hole Wash fault, western limit of the Imbricate fault system, Abandoned Wash fault, and Ghost Dance fault all are assumed to require a 60 meter standoff. The only exception is the Ghost Dance fault, which, for design considerations, has a 120 meter standoff on the west ${ }^{2}$.

\section{OVERBURDEN}

Based on the postclosure guidelines specified in the General Guidelines for the Recommendation of Sites for Nuclear Waste Repositories (10CFR960), a minimum emplacement overburden of 200 meters is assumed for the repository area ${ }^{5}$. This criteria is a long-term waste isolation consideration intended to prevent erosion from exposing the underground facility and emplaced waste packages.

\section{REPOSITORY HOST HORIZON}

The volcanic ashflow tuff units at Yucca Mountain have been subdivided into thermal/mechanical units to address engineering properties of the rock. These units group rocks that have similar thermal and mechanical properties based on correlation with their grain density and porosity. These properties are reflected, to a large extent, by the general degree of welding and the content of lithophysal cavities. Lithophysae are bubble-like structures composed of concentric zones of vapor-phase mineralization. Commonly, they contain a central cavity that may be a few millimeters across to as large as a meter, and are concentrated in stratigraphic zones separated by zones generally void of lithophysae. 
The repository host horizon was originally identified by Sandia as the TSw 2 unit, which consists of densely welded, devitrified, ashflows of the Topopah Spring Tuff that contains less than approximately ten percent of lithophysal cavities by volume ${ }^{6}$. Overlying the TSw 2 unit is TSw I, a densely welded, devitrified, ashflow tuff with generally greater than ten percent of lithophysal cavities by volume in the part directly overlying the TSw 2 unit. Underlying the TSw2 unit is TSw3, a densely welded vitrophyre.

In the $\mathrm{M} \& \mathrm{O}$ investigation for defining the potential repository block, it was found that the lower 5 to 40 meter section of the overlying TSw1 unit may be similar in thermal and mechanical characteristics to the TSw2 unit, and therefore may be suitable for repository development ${ }^{3}$. The top of this section corresponds to a noticeable change in density, as revealed in down-hole geophysical density logs, and a significant change in lithophysal cavity content, based on estimates from core. Investigation of the repository host horizon is continuing, but preliminary indications favor this upper limit within the TSw1 unit as the most suitable top of the repository host horizon.

For the M\&O Lynx model YMP.MO2, the repository host horizon was defined as including the TSw2 unit plus the overlying 5 to 40 meter section of the TSw1 unit, as identified above ${ }^{3}$. For engineering considerations, a 5-meter standoff from the top of the repository host horizon is used as the upper limit for repository siting? ${ }^{7}$. For the lower limit, a 30-meter standoff was used because of thermal design requirements ${ }^{2}$.

\section{GROUNDWATER}

In the Environmental Assessment document ${ }^{8}$, it is stated that the repository must be sufficiently above the groundwater table such that the groundwater does not encounter the emplacement host rock. The groundwater level used in the model was developed by the U.S. Geological Survey'. Within the Primary Area, the groundwater table is about 110 to 400 meters below the bottom of the repository host horizon, therefore, the groundwater table is not a limiting factor.

\section{POTENTIAL REPOSITORY SITING BLOCK}

The potential repository siting block is delineated spatially by the following physical limits:

Upper Limits:

- 200-meter overburden

- 5-meter standoff below top of repository host horizon
Lower Limits:

- 30-meter standoff above bottom of repository host horizon

. top of groundwater surface

Lateral Limits:

- 60-meter standoff from major faults (120-meters from the west side of the Ghost Dance fault)

Based on these limits, the potential repository siting block was defined within the Lynx model. A plan view of this volume, projected to a horizontal plane, is illustrated in Figure 1. Because the Primary Area is divided by the Ghost Dance fault, the block consists of an upper and lower subunit.

To illustrate this 3-dimensional volume in 2-dimensions, plan view sections were developed through the block within the planes of the current, two-level repository design, and at various distances above and below these repository levels. The resulting plan views reveal the potential repository siting areas at specific positions within the potential repository siting block. The potential repository siting areas at the repository levels are illustrated in Figure 2.

\section{IMPLICATIONS TO DESIGN}

The new potential repository siting block is a more precise definition of the available volume for repository siting than the previous, more general Primary Area. It has proven to be a valuable tool for locating the optimal position for the repository, and enabled the evaluation of a potential multi-leveled repository system. Since the Lynx system was used in the evaluation, it is relatively easy to modify the model to reflect updated geology, revised criteria, or refined engineering requirements.

\section{REFERENCES}

1. Mansure, A.J. and T.S. Ortiz, Preliminary Evaluation of the Subsurface Area Available for a Potential Nuclear Waste Repository at Yucca Mountain, Sandia National Laboratories, Sandia Report SAND81-0175 (1984).

2. Civilian Radioactive Waste Management System, Management \& Operating Contractor, Controlled Design Assumptions Document, CRWMS M\&O Doc. No. B00000000-01717-4600-00032, Rev. 02 (Dec 1995)

3. Civilian Radioactive Waste Management System, Management \& Operating Contractor, Definition of the Potential Repository Block, CRWMS M\&O Doc. No. BC0000000-01717-5705-00009, Rev. 00 (April 1995) 
4. U.S. Geological Survey, Documentation for Distribution of Lithostratigraphic Units Within the Central Block of Yucca Mountain, Nevada, Version YMP.RI.1, U.S. Geological Survey, Yucca Mountain Branch, Rock Characteristics Section, Denver, Colorado (Aug 1994)

5. 10CFR60 (Code of Federal Regulations, 10 CFR Part 960), General Guidelines for the Recommendation of Sites for the Nuclear Waste Repositories: Federal Register, U.S. Government Printing Office, Washington, D.C. (Jan. 1, 1992)

6. Ortiz, T.S., R.L. Williams, F.B. Nimick, B.C. Whittet, and D.L. South, A Three-Dimensional Model of Reference Thermal/Mechanical and Hydrological Stratigraphy at Yucca Mountain, Southern Nevada, Sandia National Laboratories, Sandia Report SAND841076 (1985)

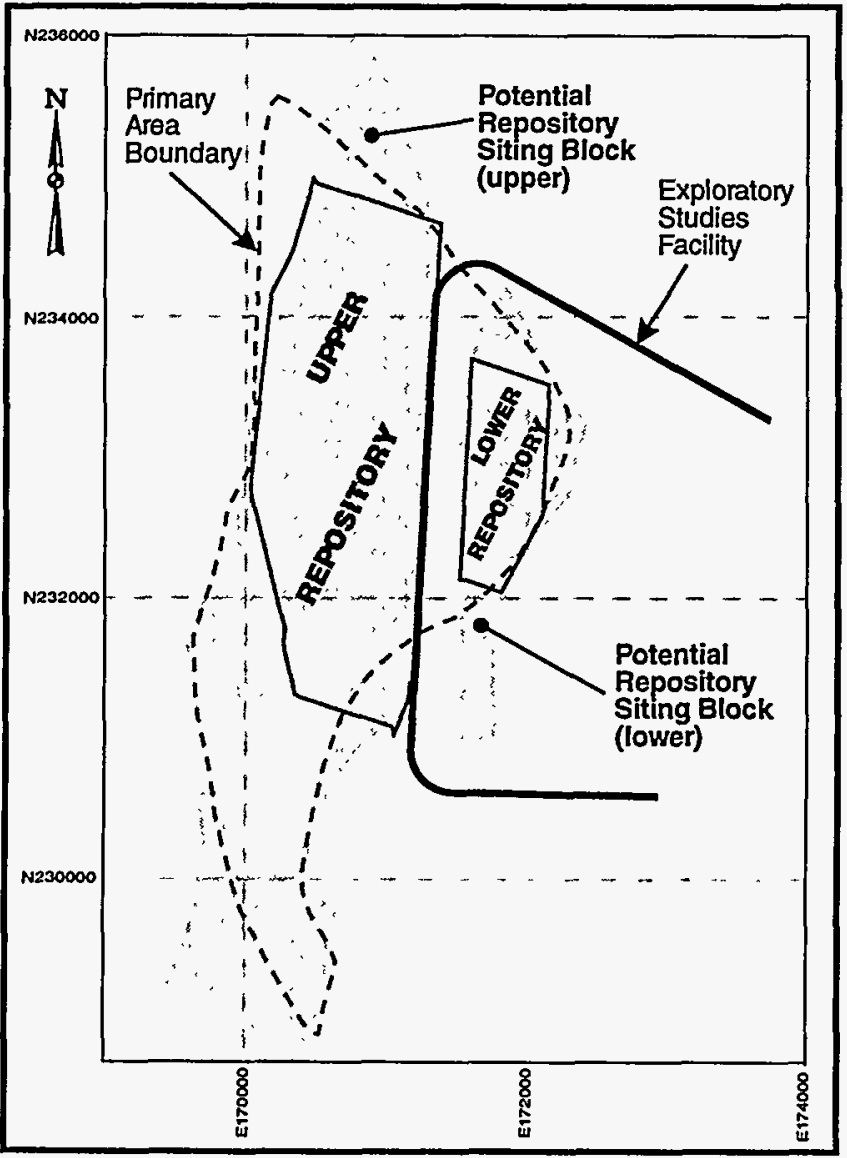

Figure 1. Plan view of potential repository siting block. The Primary Area, Exploratory Studies Facility, and the upper and lower repositories are shown for reference.
7. Civilian Radioactive Waste Management System, Management \& Operating Contractor, Recommended Layout Concepts Report, CRWMS M\&O Doc. No. BCAA00000-01717-5705-00001, Rev. 00 (July 1995)

8. Department of Energy, Office of Civilian Radioactive Waste Management, Environmental Assessment, Yucca Mountain Site, Nevada Research and Development Area, Nevada, DOE OCRWM, Washington, D.C., Doc. No. DOE/RW-0073 (May 1986)

9. Ervin, E.M., R.R. Luckey, and D.J. Burkhardt, "Summary of Revised Potentiometric Surface Map for Yucca Mountain and Vicinity, Nevada," Proceedings of the Fourth Annual International Conference on High Level Radioactive Waste Management, Las Vegas, Nevada, April 26-30, 1993, p. 1554-1558, American Nuclear Society, La Grange Park, Illinois, (1993)

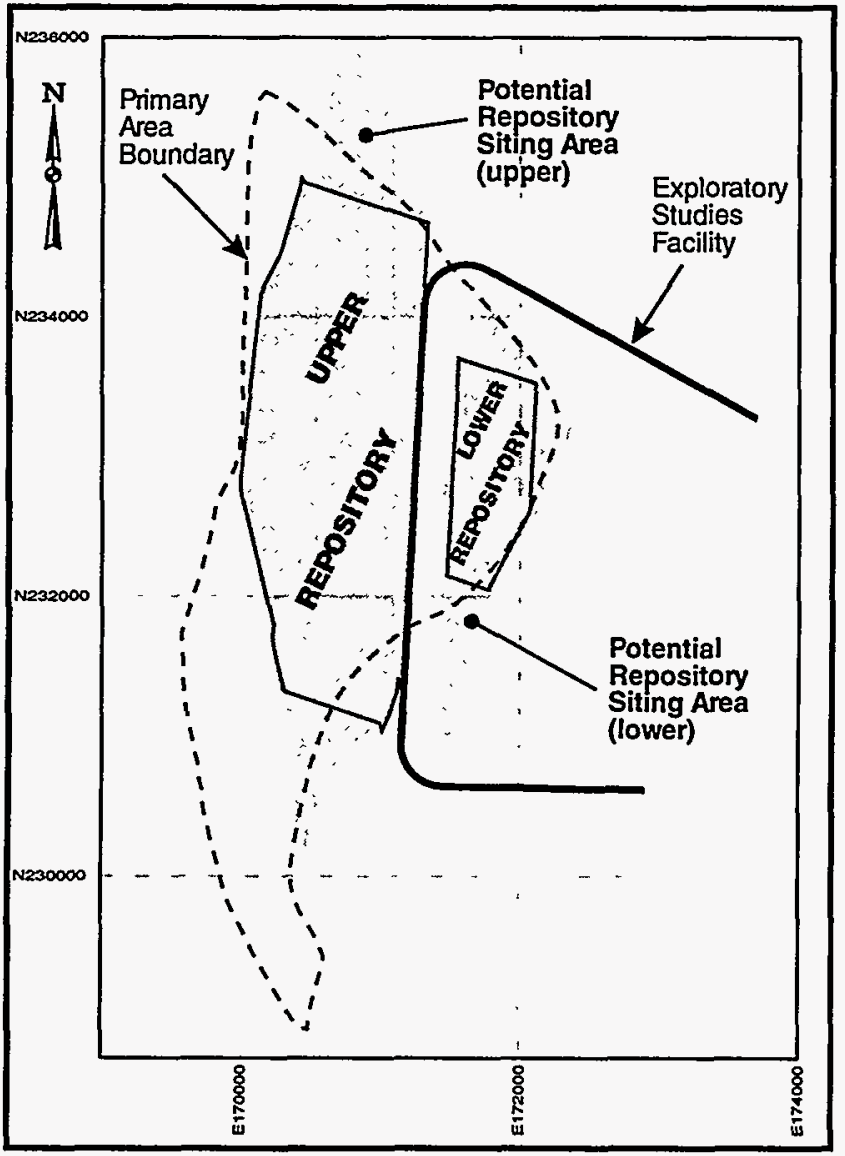

Figure 2. Potential repository siting areas within planes through the upper and lower repositories. The Primary Area, Exploratory Studies Facility, and the upper and lower repositories are shown for reference. 


\section{DISCLAIMER}

This report was prepared as an account of work sponsored by an agency of the United States Government. Neither the United States Government nor any agency thereof, nor any of their employees, makes any warranty, express or implied, or assumes any legal liability or responsibility for the accuracy, completeness, or usefulness of any information, apparatus, product, or process disclosed, or represents that its use would not infringe privately owned rights. Reference herein to any specific commercial product, process, or service by trade name, trademark, manufacturer, or otherwise does not necessarily constitute or imply its endorsement, recommendation, or favoring by the United States Government or any agency thereof. The views and opinions of authors expressed herein do not necessarily state or reflect those of the United States Government or any agency thereof. 